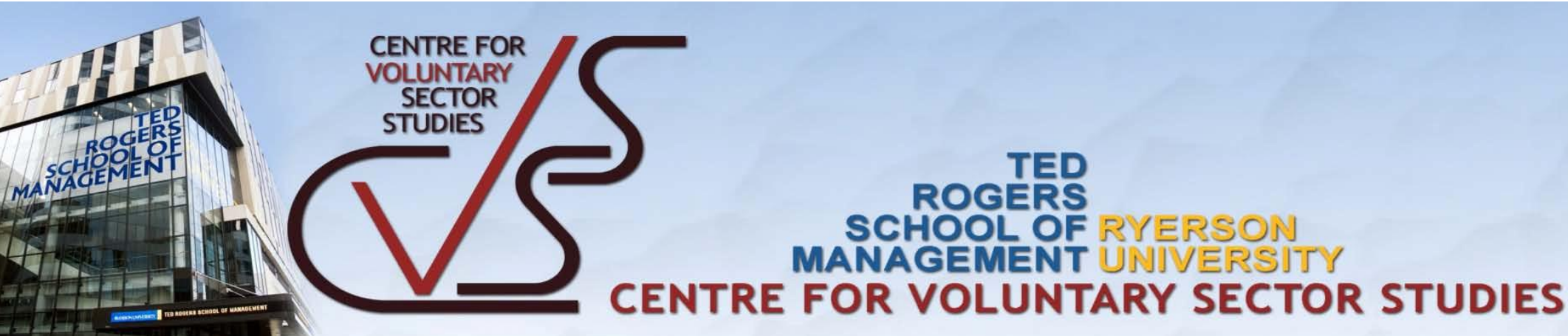

\title{
Corporate Social Responsibility in the Canadian Context: The New Role of Corporations in Community Involvement and Social Issues ${ }^{1}$
}

\author{
Mary Foster and Agnes Meinhard
}

Centre for Voluntary Sector Studies, Ryerson University

Working Paper Series

Volume 2002 (1)

350 Victoria Street

Toronto, Ontario, M5B 2K3

Tel: (416) 979-5000 x 6739 Fax: (416) 979-5124

cvss@ryerson.ca

http://www.ryerson.ca/cvss/working_papers/

\footnotetext{
${ }^{1}$ We gratefully acknowledge the assistance on data collection and preliminary analysis provided by our two research assistants, Mary Sum and Louise Moher.
} 


\section{INTRODUCTION}

The rapidly growing literature investigating corporate social responsibility (CSR) attests to the world-wide interest in this trend, both from an academic perspective and as a legitimate component of commercial success (Burson-Marsteller, 2000; Waddock \& Graves, 1997). To date, most of the research has been conducted in the US, and indeed research interest in this topic dates back to the 1930s and 1940s (Carroll, 1999). The body of knowledge about CSR in Canada is more modest and has mostly focused on investigating social disclosure from an accounting perspective (Levin, 1982; Zeghal \& Ahmed, 1990). One reason for this narrow focus has been historical. Unlike in the US, the Canadian government has been the primary architect, builder and funder of the social safety net. Until very recently, this dominant role of government has preempted the need for widespread corporate participation in the provision of social services. Thus tracking the nature and scope of CSR activities in the private sector has not been a major area of interest for Canadian researchers. Indeed, as recently as the 1980s, much of the CSR focus in Annual Reports of Canadian companies was on internal human resource issues such as employee health, safety and training, and not on community and social service issues (Zeghal \& Ahmed, 1990).

Even though social expenditures still remain the largest single spending area of the Canadian federal budget (Prince, 1999), there has been a shift in policy at all levels of government. Both the range of services and the amount of funding to nonprofit service providers have been severely reduced (Hall \& Banting, 2000). As a result, voluntary organizations have been diversifying their funding sources, including seeking corporate donations (Foster \& Meinhard, 2002). At the same time, businesses in Canada are recognizing the value of relationships with the voluntary sector both from a marketing perspective and in response to their shareholders' concerns for community involvement and social issues (Pinney, 2001; Schmid \& Meinhard, 2000). A recent Canadian opinion poll shows that $74 \%$ of shareholders say business should pursue social responsibilities, not just profits (Canadian Democracy and Corporate Accountability Commission, 2002). This paper will examine the current state of disclosure of CSR activities in the Annual Reports and Websites of Canadian companies operating in Ontario.

\section{REVIEW OF LITERATURE}

\section{Definitions}

Much of the current academic research on CSR builds on Carroll's (1979) four-part definition that states that: "the social responsibility of business encompasses the economic, legal, ethical and discretionary expectations that society has of organizations at a given point in time" (pg. 500). Over the last twenty years, many researchers have enhanced and reframed this initial construct (Aupperle, Carroll, \& Hatfield, 1985; Cochran \& Wood, 1984; Wood, 1991) and expanded the discussion to include business ethics (Reed, 1999; Sudhir \& Murthy, 2001; Verschoor, 1998), stakeholder theory (Argandona, 1998; Ruf, Muralidhar, Brown, Janney, \& Paul, 2001), and corporate social performance (Carroll, 1999; Swanson, 1995; Swanson, 1999). 
It has been suggested that corporate social performance (CSP) is a more comprehensive theory under which CSR might be subsumed (Carroll, 1999). Wartick and Cochran (1985) were the first to suggest corporate social performance was a three-dimensional integration of responsibilities, responsiveness and social issues. Woods (1991) further refined this concept to define CSP as: " a business organization's configuration of the principles of social responsibility, processes of social responsiveness, policies, programs and observable outcomes as they relate to the firm's societal relationships" (pg. 693).

The literature also discusses corporate citizenship, again building on Carroll's four-part definition of CSR (Carroll, 1999). Maignan and Ferrell (2000) define it as "the extent to which businesses meet the economic, legal, ethical and discretionary responsibilities imposed on them by their stakeholders" (pg. 285).

For the purposes of this paper, we are focusing on two key variables: the prominence given to social disclosure in reporting documents (which we will call CSR), and the assessment of a company's performance in terms of CSR principles (which we will call CSP).

\section{CSR in Canada}

Given that US researchers have done most of the theoretical work in corporate social responsibility and that the US has a particular historical context, a key question is whether CSR applies cross-nationally. Maignan and Ferrell (2000) compared CSR in France and the US to determine the cross-cultural applicability of Carroll's (1979) construct. France is more similar to Canada than the US in that social welfare is a government responsibility. Despite lower public sector involvement in the US than in France, the researchers concluded that the CSR model applied equally to both countries.

The role of government in Canada also differs sharply from the US. The provision of universal social programs by government goes beyond welfare ideology in that it plays a significant role in uniting a geographically dispersed population and in giving Canada a distinctive North American identity (Smardon, 1991). The post World War II years in Canada saw the growth of the third sector mostly along the lines of the complementary model described by Salamon $(1987,1995)$. This quasi-symbiotic relationship was the natural expression of the pluralist, liberal social welfare philosophy, which underpinned policy development during this period. Governments at all levels encouraged the formation of voluntary organizations. By the mid-1970s, the federal and provincial governments had largely completed the construction of the social welfare system, which involved a matrix of programs and services delivered by both the public and voluntary sectors. Under this structure, nonprofit organizations were part of an elaborate system that extended specialized services to the public that the government was uninterested in or unable to provide.

Since the mid-1980s the political philosophy in Canada has been changing from a pluralist, social welfare conception of State to a neo-conservative philosophy (Jeffrey, 1999; McBride \& Shields, 1997). Proponents believe that market forces should dictate the formation 
and survival of all organizations, including nonprofit organizations. Funding for nonprofit organizations should come from private charitable support and user fees, not from government. At the same time as government has cut direct tax dollars to the third sector, it has altered tax policies to encourage greater charitable giving to nonprofits (Pal, 1997). Interestingly, even during a time of neo-conservative resurgence across the world, $60 \%$ of Canadians want to strengthen government commitment to the social safety net (Graves, 1999). At the same time, Canadians are concerned that the forces of globalization are accelerating a shift in priorities from domestic welfare considerations to global economic strategies (Johnson, McBride, \& Smith, 1994).

As a result of this shift in political philosophy, there is a newly expressed concern that in addition to government support of universal social programs, corporations should act as responsible social citizens by contributing their fair share to the health and well-being of the communities in which they operate. Eighty percent of the population and $75 \%$ of corporate shareholders believe that government should establish standards for CSR. Indeed, Canada has set up a formal commission to investigate CSR and accountability because of the strongly held belief that market forces and self-regulation will not be sufficient to guarantee the standards of behaviour desired by Canadians (Canadian Democracy and Corporate Accountability Commission, 2002). As is the pattern with issues of broad-based concern, CSR is being researched and managed by a government-organized commission which is recommending how standards for CSR can be mandated in Canada. Interestingly, 84\% of Canadians feel that Canada should set corporate accountability standards itself even if other countries do not (Canadian Democracy and Corporate Accountability Commission, 2002).

\section{Disclosure of CSR Activities}

Disclosing CSR activities in Annual Reports has been characterized as a marketing tool (Levin, 1982) and as a way of anticipating or avoiding social pressure (Parker, 1986). Since Annual Reports are used by companies primarily to report financial information to investors and shareholders, this marketing role is secondary. Indeed, the scope of CSR disclosure is limited by the relative rigidity of format and the rules and procedures that govern the production and dissemination of Annual Reports (Parker, 1982). Because other vehicles such as advertising and brochures may be more appropriate to disseminate marketing- and public-relations-oriented communications (Preston, 1981), some believe that it may not be reliable to judge corporate social performance solely on the disclosures made in Annual Reports (Beresford \& Cowen, 1979). On the other hand, it could be argued that since all companies are bound by the same reporting rules for their Annual Reports that the amount of discretionary space they choose to allocate to the reporting of CSR activities is an indication of their priority within the organization.

Other research has investigated the characteristics of companies that can influence the prominence given to CSR activities. Patten (1991) and Trotman and Bradley (1981) found that larger companies report more CSR activities in their Annual Reports. Larger companies may also be more profitable, and thus may have the resources to make CSR a priority. Although Esrock and Leichty (1998) found no significant differences between six industry categories on overall 
social responsibility, other research has indicated that companies with more contact with the public give more to charity (Fry, Keim \& Meiners, 1982). Fry and Hoch (1976) also found that companies in industries with a poor public image put more emphasis on reporting socially responsible activities.

Recent research on the choice of media vehicle for social disclosure indicates there has been a shift. In a study conducted on the largest Canadian banks and petroleum companies in Canada, it was found that advertisements and brochures were not widely used in the 1980s as a means of disclosing social information (Zeghal \& Ahmed, 1990). The digital revolution has provided more choices for companies. As Esrock and Leichty (1998) discovered in their analysis of the social disclosure strategies of a sample of Fortune 500 companies, $90 \%$ of companies had Websites; and at least one corporate responsibility issue was addressed in $82 \%$ of the Websites. Given the increasing importance of the Internet as a communications and marketing tool, it would be expected that even more companies would be choosing Websites as the venue for social disclosure.

\section{The relationship among CSR, CSP and financial performance}

As Esrock and Leichty (1998) point out, one of the limitations of their study was that they were unable to relate how corporations reported on CSR with actual CSP. Ullman (1985) in his review of research done up to the mid-1980s on the relationship among social disclosure, social performance and financial performance noted the inconclusive results, which he attributed to conceptual and measurement problems particularly with social performance.

More recent research has focused on the relationship between social performance and financial performance, with many studies using the Fortune Corporate Reputation Index as a measure of social performance. In their review of the past research conducted on this topic, Stanwick and Stanwick (1998) also point out the conflicting results. While some studies find evidence of a significant positive relationship between social and financial performance, others do not. In their own study, they confirm the usefulness of the Reputation Index by showing significant relationships between CSP and profitability, CSP and size of the company and an inverse relationship between CSP and pollution emissions, which has been used in other studies as a proxy for CSP. Their research supports the results of Waddock and Graves' (1997) study, which also found a positive relationship between CSP and financial performance.

In research conducted on corporate responsiveness among four large forestry companies in Canada and Finland from 1976 to 1991, it was discovered that economic performance was a major influence. During periods of low economic performance, there was a precipitous decline in the attention paid to social issues and social performance (Näsi, Näsi, Phillips, \& Zyglidopoulos, 1997), suggesting that prior to 1991 at least among natural resource companies, CSR is still seen as a luxury and not a necessity for economic viability. 


\section{RESEARCH QUESTIONS}

This study explores the public relations prominence given to CSR activities among Ontariobased Canadian companies listed on the TSX 300. Canada is an interesting case study because not only has there been significant government involvement in supporting social welfare programs, but also its citizens are very supportive of this prominent government role (Graves, 1997). It is within this historical and attitudinal framework that Canadian corporations have created their CSR priorities.

Specifically, it seeks to describe:

1) The influence of industry sector and size on the public relations prominence accorded CSR activities. We expect that if Ontario-based Canadian companies follow the patterns of their US counterparts that larger companies (Patten, 1991; Trotman \& Bradley, 1981) and those with more interaction with the public (Fry, Keim \& Meiners, 1982) will give more prominence to CSR activities in their Annual Reports and Websites.

2) The relationship between public relations prominence of CSR activities and performance. If Ontario-based Canadian companies emulate their American counterparts, we expect that financial performance will be tied to corporate social performance (Stanwick \& Stanwick, 1998; Waddock \& Graves, 1997).

\section{METHOD}

\section{Sample Design}

Using the SEDAR database (System for Electronic Document Analysis and Retrieval), 119 companies were identified from the TSX 300 index of public companies that had the following features:

- Canadian-owned. No "branch plants" from the US or other foreign companies were included.

- A current base of operations in Ontario (e.g. physical assets or human resources), although the head office could be based in another province.

- An Annual Report available for 2001.

- An operating Website.

\section{Data Collection}

Three secondary sources of information were used to create a CSR profile for all the companies that met the criteria outlined in the sample design.

\section{Annual Reports}

Information (if available) obtained from the Annual Report included: 
- Name of company and address of head office

- Net profits for 2001

- Website URL

- Number of employees

- $\$$ amount donated to CSR activities in 2001

- Membership in the Imagine program ${ }^{2}$

- CSR interests and focus

- Availability of separate CSR report

The prominence of the reporting of CSR activities was evaluated according to the following scale:

- 1 page or more plus photo 5

- 1 page, no photo 4

- one-half page 3

- paragraph 2

- few lines 1

- no mention 0

\section{Website}

The prominence of the reporting of CSR activities was evaluated according to the following scale:

- section on CSR 3

- page 2

- paragraph mention 1

- no mention 0

The scale for Annual Reports and Websites is not the same because of the differences between these two media. It is much easier to differentiate between page, paragraph and lines in a standard page in an Annual Report than it is in a Website. Because evaluating the latter is dependent on individual browser settings and screen size, much broader categories were used for the Website ratings.

\section{Canadian Social Investment Database}

For the past ten years, Michael Jantzi Research Associates Inc. (MJRA) has been tracking publicly traded Canadian companies and providing analysis to institutional and individual investors who consider social and environmental performance when making investment decisions. Corporate citizenship rankings have been developed based on 200 indicators and subindicators of social and environmental performance. The scores for each indicator have been weighted and tabulated and share performance has also been incorporated into the final score for

\footnotetext{
${ }^{2}$ To be a member of this program, a company must make a commitment: 1 ) to donate a minimum of $1 \%$ of average, domestic pre-tax profits to the charitable, nonprofit organizations of its choice; 2) to encourage and support employee giving and volunteering; 3) to support suppliers whose business is ethically and environmentally sound; and 4) to share its business expertise and premises with its community.
} 
each company. Only those whose rankings are deemed by an advisory panel of leading individuals from business, NGOs, government and the media to be as fair to the facts as possible make the list of Best 50 Corporate Citizens in Canada Annual Ranking. The companies on the Best 50 list were matched with the TSX 300 companies that met the criteria for inclusion in this study. Of the 119 in the sample, 26 were on the Best 50 Corporate Citizen list.

\section{RESULTS}

Overall, the average prominence for CSR activities in Annual Reports of the 119 Ontariobased Canadian companies in the study was 1.4 (between a few lines and a paragraph), and for a Website, it was 1.2 (between a paragraph and a dedicated page). As might be expected there is a significant correlation between Annual Report and Website prominence $(\mathrm{r}=.647, \mathrm{p}=.000)$. One reason for a higher prominence of CRS on Websites is the space limitations of the paper document. While Websites can be updated continuously, Annual Reports are only produced once a year. In addition, these two public relations vehicles have different purposes. The latter is mostly used for financial reporting to shareholders, while the former has a broader marketing focus.

\section{Factors Influencing Prominence}

The literature has indicated that while CSR is a concept that applies cross-nationally, there are differences in the prominence accorded CSR by company characteristics. For example, specific industries may be more motivated than others to give CSR prominence on account of the particular goods and services with which they are associated. In addition, company size is a factor that influences many behaviours including CSR. Larger companies may be more in the public eye and thus subject to scrutiny. Larger companies may also have more resources and may be more able to invest in CSR.

\section{Industry Sector}

The sampled companies were coded into ten categories: natural resources, industrial products, technology products, communications/business services, food and alcohol, financial services, consumer, specialty and other, health service, insurance companies and mutual fund companies. $^{3}$

As Chart 1 indicates companies in natural resources, food and alcohol and finance sectors are the ones likely to give the most prominence to CSR activities in Annual Reports and Websites. For Annual Reports the differences are statistically significant (chi-square $=72$. 631, $\mathrm{df}=1,45, \mathrm{p}=.006)$, but for Websites they are not $(\mathrm{p}=.112)$.

\footnotetext{
3 Mutual Fund companies were separated from other financial institutions because of their size and asset differentials. A pilot study comparing the two sectors showed major differences in data available on CSR.
} 


\section{Chart 1: Prominence by Industry Code ( $n=119$ companies)}

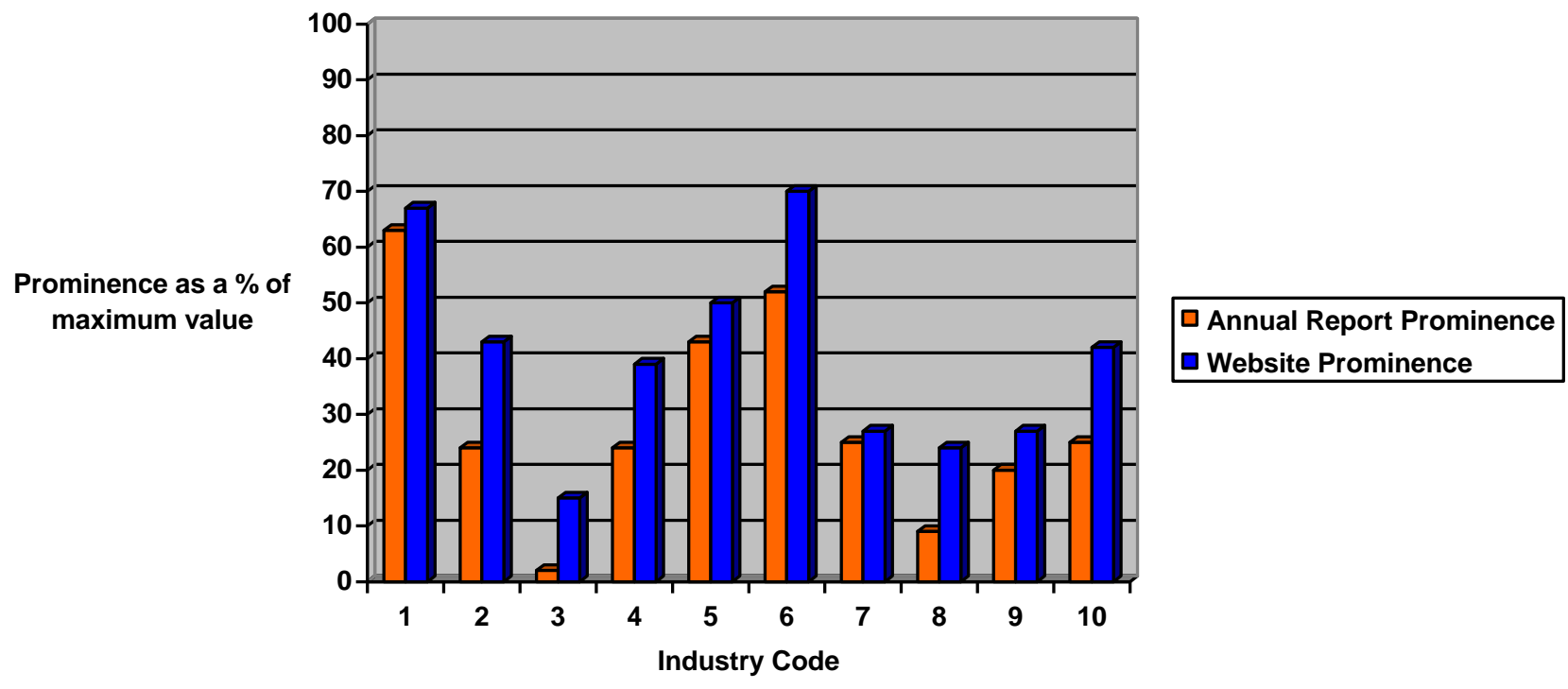

Prominence values were calculated as follows: Individual companies were coded using the scale described below for Annual Reports and Websites. An average was calculated for each industry and that average was then divided by the maximum value of the scale to obtain a percentage of the highest possible value.

For Annual Report:

1 page or more plus photo

1 page, no photo

$1 / 2$ page

paragraph

few lines

no mention
For Website:

section on CSR

page $\quad 2$

paragraph mention $\quad 1$

no mention 0
Industry Classification

Code 1 = Natural Resources $(n=14)$

Code $3=$ Technology products $(\mathrm{n}=20)$

Code $5=$ Food and Alcohol $(n=8)$

Code 7 = Consumer, Specialty and other (includes transportation,

travel, consumer, real estate, furniture, etc. $(n=15)$

Code $9=$ Insurance Companies $(\mathrm{n}=5)$
Code 2 = Industrial products $(\mathrm{n}=16)$

Code $4=$ Communications and business services $(n=19)$

Code $6=$ Financial Institutions $(n=10)$

Code $8=$ Health Services $(\mathrm{n}=7)$

Code $10=$ Mutual Fund Companies $(n=4)$

Another interesting result relates to the discrepancies between Annual Report and Website prominence. As Table 1 illustrates, industrial products, financial institutions, mutual fund companies, communications and business services, health services and technology products all have a discrepancy of more than $10 \%$ between Annual Reports and Website prominence. For these sectors, one could argue that CSR is evolving into a marketable asset as evidenced by the higher priority given to CSR on the Website compared to the Annual Report. In companies with less of a discrepancy, CSR may already be more embedded in the culture and thus has a high prominence in both public relations vehicles (eg. Natural resources, food and alcohol), or the commitment may have plateaued at a lower level (eg. Insurance companies). 
Table 1: Discrepancy between prominence on Annual Report and Website by industry sector

\begin{tabular}{|l|c|}
\hline Industry Sector & Discrepancy in Prominence $^{*}$ \\
\hline Natural resources $(\mathrm{n}=14)$ & $4 \%$ \\
\hline Industrial products $(\mathrm{n}=16)$ & $19 \%$ \\
\hline Technology products $(\mathrm{n}=20)$ & $13 \%$ \\
\hline Communications and business services $(\mathrm{n}=19)$ & $15 \%$ \\
\hline Food and alcohol $(\mathrm{n}=8)$ & $7 \%$ \\
\hline Financial institutions $(\mathrm{n}=10)$ & $18 \%$ \\
\hline Consumer, specialty and other $(\mathrm{n}=15)$ & $2 \%$ \\
\hline Health services $(\mathrm{n}=7)$ & $15 \%$ \\
\hline Insurance companies $(\mathrm{n}=5)$ & $7 \%$ \\
\hline Mutual fund companies $(\mathrm{n}=4)$ & $17 \%$ \\
\hline
\end{tabular}

* Calculated by subtracting the prominence as a \% of maximum value in the Annual Report from the prominence as a $\%$ of maximum value on the Website.

Size

Size is operationalized as net profits reported and total number of employees. As Table 2 indicates, when the subset of the top 10 profit makers is compared to the sample as a whole, it is clear that CSR activities are given a much higher prominence in larger companies. In Annual Reports, on average, large companies devote between one-half page to a full page to report on CSR activities, compared to between a few lines and a paragraph in the sample as whole. On Websites, large companies on average devote between one page and a whole section to CSR. The same patterns are found for the ten companies with the largest number of employees.

Table 2: Prominence of CSR activities by size of company

\begin{tabular}{|l|c|c|}
\hline Companies on TSX 300 & $\begin{array}{c}\text { Average Prominence } \\
\text { in Annual Report } \\
\text { (Range 0 -5) }\end{array}$ & $\begin{array}{c}\text { Average Prominence } \\
\text { on Website } \\
\text { (Range 0 -3) }\end{array}$ \\
\hline Total sample $(\mathrm{n}=119)$ & 1.4 & 1.2 \\
\hline Largest 10 by profit & 3.7 & 2.4 \\
\hline Largest 10 by number of employees & 4.0 & 2.9 \\
\hline
\end{tabular}

Companies that report the dollars donated $(n=13)$ are also significantly more likely to give CSR more prominence in their Annual Reports (chi-square $=39.855, \mathrm{df}=1,5, \mathrm{p}=.000$ ), and on their Website (chi-square $=29.615$, df $=1,3, \mathrm{p}=.000$ ).

\section{Relationship to Performance}

Using the MJRA ranking, companies in the sample were divided between those in the top 50 and those that were not. Those in the top $50(\mathrm{n}=26)$ were significantly more likely to:

- report the dollar amount donated for CSR activities (chi-square $=10.189$, $\mathrm{df}=1,1, \mathrm{p}=$ $.000)$. 
- be a member of the Imagine Caring Company program (chi-square $=7.350, \mathrm{df}=1,1, \mathrm{p}=$ .007).

- devote more space to CSR on their Website (chi-square $=10.420, \mathrm{df}=1,3, \mathrm{p}=.015$ )

- produce a separate document reporting on CSR activities (chi-square $=5.067, \mathrm{df}=1,1, \mathrm{p}$ $=.024)$

The top 50 corporate citizens are also more likely to devote more space to CSR in their Annual Reports, but the differences are not statistically significant $(\mathrm{p}=.108)$.

Table 3 shows how the largest Canadian companies compare on likelihood to be in the Top 50 listing and to be part of the Imagine program

Table 3: Percent in the Top 50 listing and part of Imagine

\begin{tabular}{|l|c|c|}
\hline Companies on TSX 300 & $\begin{array}{c}\text { Percent on Top 50 Best } \\
\text { Corporate Citizen list } \\
\text { (Range 0 to 100\%) }\end{array}$ & $\begin{array}{c}\text { Percent part of the } \\
\text { Imagine program } \\
\text { (Range 0 to 100\%) }\end{array}$ \\
\hline Total sample $(\mathrm{n}=119)$ & $22 \%$ & $32 \%$ \\
\hline Largest 10 by profit & $50 \%$ & $60 \%$ \\
\hline Largest 10 by number of employees & $50 \%$ & $70 \%$ \\
\hline Largest 10 by reported \$ donated & $69 \%$ & $85 \%$ \\
\hline
\end{tabular}

If CSR were unrelated to company characteristics then we would expect the number of Top 50 corporate citizens and members of the Imagine program to be distributed randomly throughout our 119 Ontario-based Canadian companies. However, the results show that larger companies are more likely to be on the Top 50 ranking and to be members of the Imagine program.

The top 10 companies by size include 5 financial institutions and 3 natural resources companies. It could be argued that these companies are more motivated to be good corporate citizens because they are more likely to be subjected to governmental regulation (Dierkes \& Preston, 1977), and also may have public pressure to be socially responsible (Carroll, 1979). However, given their ranking on the Top 50 list, the large companies do more than talk about CSR, they also perform in more socially responsible ways. In addition, they are more likely to enter into a formal arrangement like the Imagine program to signify the strength of their commitment to CSR.

\section{DISCUSSION}

The purpose of this study was to describe the current state of disclosure of CSR activities in the Annual Reports and Websites of Ontario-based Canadian companies in the context of the historical role of government in supporting social services. We found that the average prominence in Annual Reports is between a few lines and a paragraph, which is very similar to the .39 of a page that was reported in a 1985 study of 156 Fortune 500 companies (Patten, 1991). The US data are used as a proxy for Canadian companies because comparable historical data are 
not available. On average then, companies have not increased the space they devote in Annual Reports to CSR activities. This finding could be a reflection of the limited flexibility in Annual Reports given the rules about financial reporting (Parker, 1982).

What is different, however, is that now Canadian companies are using their Websites as marketing vehicles and devoting space to reporting CSR activities (between a paragraph and a dedicated page, on average). While in the 1980s, advertising and brochures were not used extensively to promote CSR activities (Zeghal \& Ahmed, 1990), by 2001, the digital revolution has provided other choices for social disclosure reporting, and companies are using them.

Another focus of this exploration was to investigate whether different industry sectors were more likely to give prominence to CSR activities. We found natural resources companies, financial institutions and food and beverage companies had the highest prominence in both Annual Reports (statistically significant) and Websites (not statistically significant). It makes sense that companies in high profile environmentally sensitive industries, such as natural resources, would have an incentive to project a positive image and give prominence to CSR. However, neither Patten's (1991) study of Fortune 500 companies nor Esrock and Leichty's (1998) study found any significant relationship between industry sector and reporting of social responsibility. Our mixed results may be a reflection of the shifts in public concerns. Environmental issues are generally more prominent, given the publicity given to the recent Walkerton water crisis, the ongoing controversy about logging in national parks and on aboriginal land, and the recent speculation about whether Canada will sign the Kyoto Protocol. As Esrock \& Leichty (1998) suggest, social responsibility issues on Websites are accorded space consistent with the prominence these topics have in general public discussion. Likewise, Fry and Hoch (1976) found that in industries with a tainted public image, like natural resources, are more prone to emphasize their commitment to CSR. A further reason for banks and food and beverage companies scoring higher is that these sectors have more direct contact with the public and research has indicated that companies with more contact with the public give more to charity (Fry, Keim \& Meiners, 1982).

This study also found that the ten largest companies gave higher levels of prominence on both their Web pages and Annual Reports to CSR activities. This is consistent with existing thought and research on the relationship between size and CSR and CSP. From a theoretical perspective, because the largest corporations affect more people, they may arouse greater scrutiny and have more calls for social responsibility (Dalton \& Kesner, 1985; Cowen, Ferreri, \& Parker, 1987). The behaviour of Ontario-based Canadian companies is consistent with US research that found larger companies provide more social responsibility information in their Annual Reports (Trotman \& Bradley, 1981; Patten, 1991) and on their Web pages (Esrock \& Leichty, 1998).

This study also found that Ontario-based Canadian companies that gave more prominence to CSR activities on their Web page and Annual Reports were also more likely to have high scores on corporate citizenship, an element of which was financial performance. This is consistent with some research on the relationship between social disclosure and financial performance. Waddock and Graves (1997) found a significant relationship between financial performance as measured by return on assets, return on equity and return on sales and corporate 
social performance (CSP) as operationalized by a number of measures including employee relations, community relations and sensitivity to the environment. The researchers concluded that a "virtuous circle" exists in that CSP is both a predictor and a consequence of financial performance.

Chen and Metcalf (1980) argued that the size of the firm is confounding the relationship between CSP and financial performance. While large firms have more stakeholders to whom they must respond (Burke, Logsdon, Mitchell, Reiner, \& Vogel, 1986; Waddock \& Graves, 1997), small firms have to be more focused on making a profit because their existence is more tenuous and they do not have the luxury of investing in discretionary activities. However, Orliztky (2001) demonstrated through a meta-analysis that when firm size is controlled for, the relationship between CSP and financial performance holds. His conclusion is that small firms can also benefit financially from engaging in CSR activities.

\section{CONCLUSION}

We conducted this study on Ontario-based Canadian firms because we wanted to investigate how social and political history may affect a corporation's perspective on CSR. Because of the significant government role in social services, it might be expected that Canadian corporations would present a different pattern from their US counterparts in terms of participating in and showcasing CSR activities. However, the results indicate that the behaviour of Ontario-based Canadian companies is consistent with the pattern of US companies. Annual Reports and Websites are used to showcase CSR activities. The prominence accorded CSR in these public relations vehicles is influenced by company size and industry sector. In addition, social disclosure is related to social performance. From these results, we conclude that on the issue of CSR, global, not national standards determine behaviour. Because Canadian companies compete in a global marketplace and for many, the US is the most important market, they must emulate US companies in all aspects of corporate behaviour and strategy, including CSR, in order to be successful. 


\section{REFERENCES}

Argandona, A. (1998) The stakeholder theory and the common good. Journal of Business Ethics, 17 (9/10), 1093-1102.

Aupperle, K.E. Carroll, A.B. \& Hatfield, J.D. (1985). An empirical investigation of the relationship between corporate social responsibility and profitability. Academy of Management Journal, 16, 691-718.

Beresford, D.R. \& Cowen, S.S. (1979). Surveying social responsibility disclosure in annual reports. Business: The Magazine of Managerial Thought and Action, 29 (2), 15-20.

Burke, L., Logsdon, J.M., Mitchell, W., Reiner, M., \& Vogel, D. (1986). Corporate community involvement in the San Francisco Bay area. California Management Review, 28 (3), 122141.

Burson-Marsteller. (2000). International opinion leader survey on corporate social responsibility. Prince of Wales Business Leaders Forum, U.K.

Canadian Democracy and Corporate Accountability Commission. (2002). The new balance sheet: Corporate profits and responsibilities in the $21^{\text {st }}$ century. Final Report.

Carroll, A.B. (1979). A three-dimensional conceptual model of corporate performance. Academy of Management Review, 4 (4), 497-505.

Carroll, A.B. (1998). The four faces of corporate citizenship. Business and Society Review, 100/101, 1-7.

Carroll, A.B. (1999). Corporate social responsibility: Evolution of a definitional concept. Business \& Society, 38 (3), 268-295.

Chen, K.H. \& Metcalf, P.R.W. (1980). The relationship between pollution control record and financial indicators revisited. Accounting Review, 55 (1), 168-177.

Cochran, P.L. \& Wood, R.A. (1984). Corporate social responsibility and financial performance. Academy of Management Journal, 27, 42-56.

Corporate Social Responsibility (CSR) Monitor . (2001). Global Public Opinion on the Changing Role of Companies. 1999 Millenium Poll on CSR, Environics International, Toronto.

Cowen, S.S. Ferreri, L.B., \& Parker, L.D. (1987). The impact of corporate characteristics on social responsibility disclosure: A typology and frequency-based analysis. Accounting, Organization and Society, 12 (2), 111-122.

Dalton, D.D. \& Kesner, I.F. (1985). Organizational growth: Big is beautiful. Journal of Business Strategy, 6 (1) 38-48.

Dierkes, M. \& Preston, L.R. (1977). Corporate social accounting reporting for the physical environment: A critical review and implementation proposal. Accounting, Organizations and Society, 2 (1), 3-22.

Esrcok, S.L. \& Leichty, C.B. (1998). Social responsibility and corporate web pages: Selfpresentation or agenda-setting? Public Relations Review, 24 (3), 305-319.

Foster, M.K. \& Meinhard, A.G. (2002). Revenue diversification as a strategic response of Canada's nonprofit sector to new government policies. Revise and Resubmit to Nonprofit Management and Leadership.

Fry, F. \& Hoch, R.J. (1976). Who claims corporate responsibility? The biggest and the worst. Business and Society Review/Innovation, 18, 62-65/

Fry, F. Keim, G. Meiners, R. (1982). Corporate contributions: Altruistic or for profit? Academy of Management Review, 25 (2), 94-106. 
Graves, F.L. (1999). Rethinking government as if people mattered: From Reagonomics to humanomics. In L.A. Pal (ed.) How Canada spends 1999-2000: Shape shifting:

Canadian governance toward the $21^{\text {st }}$ century, (pp.37-73). Oxford University Press Canada.

Hall, M. \& Banting, K.G. (2000). The nonprofit sector in Canada: An introduction. In K.G. Banting (Ed.), The nonprofit sector in Canada: Roles and relationships (pp. 1-28). Montreal and Kingston: School of Policy Studies, Queen's University.

Jeffrey, B. (1999). Hard Right Turn: The New Face of Neo-Conservatism in Canada. Toronto: HarperCollins Publishers, Inc.

Johnson, A.F., McBride, S. \& Smith, P.J. (1994). Introduction. In Johnson, A.F., McBride, S. and Smith, P.J. (Eds.) Continuities and Discontinuities: The Political Economy of Social Welfare and Labour Market Policy in Canada. Toronto: University of Toronto Press.

Levin, A.E. (1982). Updating social responsibility. Canadian Banker and ICB Review, 89 (5), 56-61.

Maignan, I. \& Ferrell, O.C. (2000). Measuring corporate citizenship in two countries: The case of the United States and France. Journal of Business Ethics, 23 (3), 283-297.

McBride, S. \& Shields, J. (1997). Dismantling a Nation: The Transition to Corporate Rule in Canada. Halifax: Fernwood Publishing.

Näsi, J., Näsi, S. Phillips, N., \& Zyglidopoulos, S. (1997). The evolution of corporate social responsiveness: An exploratory study of Finnish and Canadian forestry companies. Business and Society, 36 (3), 296-321.

Orlitzky, M. (2001). Does firm size confound the relationship between corporate social performance and firm financial performance. Journal of Business Ethics, 33 (2), 167-180.

Pal, L.A. (1997). Civic re-alignment : NGOs and the contemporary welfare state. In R.B. Blake, P.E. Bryden, and J. F. Strain (Eds.), The Welfare State in Canada: Past, Present and Future. Concord: Irwin Publishing

Parker, L.D. (1986). Polemical themes in social accounting: A scenario for standard setting. In M. Niemark, B. Merino, \& T. Tinker (Eds.), Advances in Public Interest Accounting, Vol. I (pp. 67-93). Greenwich: JAI Press Inc.

Parker, L.D. (1982). Corporate annual accounting: A mass communications perspective. Accounting and Business Research, Autumn, 279-286.

Patten, D.M. (1991). Exposure, legitimacy and social disclosure, Journal of Accounting and Public Policy, 10, 297-308.

Pinney, C. (June, 2001). More than Charity: Building a New Framework for Canadian Private Voluntary Sector Relations. Discussion Paper for Imagine's Voluntary Sector Forum, Canadian Centre for Philanthropy, Toronto.

Preston, L.E. (1981). Research on corporate social reporting: Direction for Development. Accounting, Organization and Society, 6 (3), 255-262.

Prince, M.J. (1999). From health and welfare to stealth and farewell: Federal social policy 19802000. In L.A. Pal (ed.) How Canada spends 1999-2000: Shape shifting: Canadian governance toward the $21^{\text {st }}$ century, (pp. 151-196). Don Mills, ON: Oxford University Press Canada.

Reed, D. (1999). The realm of corporate responsibility: Distinguishing legitimacy, morality and ethics. Journal of Business Ethics, 21 (1) 23-35.

Ruf, B.M. Muralidhar, K., Brown, R.M., Janney, J.J. \& Paul, K. (2001). An empirical investigation of the relationship between change in corporate social performance and 
financial performance: A stakeholder perspective. Journal of Business Ethics, 32 (2), 143-156.

Salamon, L.M. (1987). Partners in service. In W.W. Powell (Ed.). The Nonprofit Sector: A Research Handbook (pp. 107-117), New Haven: Yale University Press.

Salamon, L.M. (1995). Partners in Public Service: Government-Nonprofit Relations in the Modern Welfare State. Baltimore: Johns Hopkins University Press.

Schmid, H. \& Meinhard, A. (2000). A Comparative Analysis of Emerging Partnerships between Corporations and Nonprofit Social Service Organizations in Canada and Israel. Presented at the annual ARNOVA Conference, New Orleans, LA. November 2000.

Smardon, B. 1991. The federal welfare state and the politics of retrenchment in Canada. Journal of Canadian Studies, 26(2), 122-141.

Stanwick, P.A. \& Stanwick, S.D. (1998). The relationship between corporate social performance and organizatinal size, financial performance and environmental performance: An empirical examination. Journal of Business Ethics, 17 (2), 195-204.

Sudhir, V. \& Murthy, P.N. (2001). Ethical challenges to businesses: The deeper meaning. Journal of Business Ethics, 30 (2), 197-210.

Swanson, D.L. (1995). Addressing a theoretical problem by reorienting the corporate social performance model. Academy of Management Review, 20 (1), 43-64.

Swanson, D.L. (1999) Toward an integrative theory of business and society: A research strategy for corporate social performance. Academy of Management Review, 24 (3) 506-521.

Trotman, K. \& Bradley, G. (1981). Associations between social responsibility disclosure and characteristics of companies. Accounting, Organizations \& Society, 6 (4), 355-362.

Ullman, A.A. (1985) Data in search of a theory: A critical examination of the relationships among social performance, social disclosure and economic performance of US firms. Academy of Management Review, 10 (3), 540-557.

Verschoor, C.C. (1998). A study of the link between a corporation's financial performance and its commitment of ethics. Journal of Business Ethics, 17 (13), 1509-1516.

Waddock, S.A. \& Graves, S.B. (1997). The corporate social performance-financial performance link. Strategic Management Journal, 18 (4), 303-319.

Wartick, S.L. \& Cochran, P.L. (1985). The evolution of the corporate social performance model: Academy of Management Review, 10, 758-769.

Wood, J.D. (1991). Corporate social performance revisited. Academy of Management Review, $16,691-718$.

Zeghal, D. \& Ahmed, S.A. (1990). Comparison of social responsibility information disclosure used by Canadian firms. Accounting, Auditing and Accountability Journal, 3 (1), 38-53. 